\title{
Determination of the In Vitro Gas Production and Potential Feed Value of Olive, Mulberry and Sour Orange Tree Leaves
}

https://doi.org/10.1515/biol-2018-0033

Received February 16, 2018; accepted April 13, 2018

\begin{abstract}
This study was conducted to determine the potential nutritive value and in vitro gas production (IVGP) parameters of Olea europaea L. (Olive = OL), Morus alba L. (Mulberry = ML) and Citrus aurantium L. (Sour orange $=\mathrm{SOL}$ ) tree leaves. Hohenheim gas test was used to determine the in vitro gas productions of the leaves. The gas production of samples over time was recorded for 3 , 6, 9, 12, 24, 48, 72 and $96 \mathrm{~h}$ after incubation. Completely Randomized Design was used to compare gas production, and gas production kinetics of samples. The findings of the present study suggested that there were differences among the tree leaves in terms of crude protein, NDF, in vitro gas productions, organic matter digestibility (OMD), metabolisable energy (ME), net energy lactation $\left(\mathrm{NE}_{\mathrm{L}}\right)$ and relative feed values $(\mathrm{RFV})(\mathrm{P}<0.01)$. ML had the highest condensed tannin contents $(\mathrm{P}<0.05)$, in vitro gas production (IVGP), OMD and energy values $(\mathrm{P}<0.01)$. SOL had highest RFV values. OL showed the lowest IVGP when compared to SOL and ML. Low NDF and ADF contents of SOL would probably increase the voluntary intake, digestibility and relative feed values of these leaves by ruminants. In conclusion, it was determined that OL, ML and SOL used in the study have low in vitro gas production and can be utilized as alternative roughage feed in ruminants. However, it is recommended that the results obtained from this research should be tested in in vivo studies.
\end{abstract}

\footnotetext{
*Corresponding author: Mustafa Olfaz, University of Ondokuz Mayis, Faculty of Agriculture, Department of Animal Science, 55139 SamsunTurkey, E-mail: molfaz@omu.edu.tr

Unal Kilic, Abdiwali Mohamoud Abdi, University of Ondokuz Mayis, Faculty of Agriculture, Department of Animal Science, 55139

Samsun-Turkey

Mustafa Boga, University of Omer Halisdemir, Bor Vocational School, 51700 Nigde-Turkey
}

Keywords: Tree leaves, in vitro gas production, energy value, relative feed value

\section{Introduction}

Fodder plants and crop residues of field, grass and pastures are mainly traditional forage sources for ruminants in the Mediterranean Region. However, roughage is required during drought seasons and winter months. For this reason, it was reported that some of the shrubs, thorny plants and tree leaves can be used as an alternative roughage feeds [1-5].

Leaves and fruits of trees are important to the nutrition of browsing ruminants such as goats, sheep, cattle and deer in the Mediterranean region. It is also known that the leaves and fruits of some trees are meeting the requirements of ruminant in semi-arid areas like as Mediterranean region [5-7]. As a result of their high nutritive value, and positive effects on rumen function, microbial yields and body metabolism, tree leaves are being increasingly recognized as a potentially high quality feed resource for ruminants, particularly to supply crude protein [8] and are exploited for livestock feeding as an energy source [9]. However, the use of tree leaves by herbivores is often restricted by the plants defence or deterrence mechanisms related to high tannin and phenolic matter contents [10-11]. Potential animal fodder plants include: Olea europaea L. (Olive), Morus alba L. (Mulberry) and Citrus aurantium L. (Sour orange), all trees abundantly found in the Mediterranean Sea region of Turkey (Adana province).

Approximately $25-30 \mathrm{~kg}$ of leaves are produced by one olive tree per year (5\% of the olive tree mass produced) and it is known that 7.0 to $12.9 \%$ dry matter (DM), crude protein contain olive leaves [12-13]. It is reported that olive leaves can be used as a low quality roughage feed in ruminants after being dried, they have similar nutritional values to 
cereal straws, and that olive leaves can be used to meet the maintenance requirement of lambs [14-16].

Mulberry tree leaves are also rich in protein (20\% of DM), it has been reported that sheep, goats and dairy cattle like to consume it and the efficiency of milk yield was increased [17-18]. Furthermore, there are studies on the essential oil and secondary metabolite contents of SOL, which is widespread in the Mediterranean region [19-20], but it has not been included in studies on the use of ruminant nutrition. In addition, it is thought that the SOL, OL and ML, which have a certain amount of phenolic contents, will reduce methane production.

Some research was carried out on the chemical composition of olive, mulberry and sour orange tree leaves [3, 22-24], but, there is limited information on in vitro gas production, energy contents and organic matter digestibility. The aim of this study was to determine the chemical composition, relative feed value, in vitro gas production parameters, energy values (metabolisable energy and net energy lactation) and organic matter digestibility of the leaves of mulberry, sour orange and olive trees growing in Southern Turkey.

\section{Materials and Methods}

\subsection{Collection of leaves and chemical analysis}

The leaves of tree were harvested in mid-August from Adana province (located at an altitude of $28 \mathrm{~m}$ above sea level) in the south of Turkey. In this study, three different tree leaves (Olea europaea L. (Olive), Morus alba L. (Mulberry) and Citrus aurantium L. (Sour orange)) were used. The leaves were hand harvested from at least 10 different trees for each sample, pooled and oven dried at $60^{\circ} \mathrm{C}$ for 48 hours. Then the leaves were milled in a hammer mill through a $1 \mathrm{~mm}$ sieve for chemical analysis. Dry matter (DM) was determined by drying samples at $105^{\circ} \mathrm{C}$ for 24 hours. Ash content was determined by ashing in a muffle furnace at $550^{\circ} \mathrm{C}$ for 8 hours. Nitrogen (N) contents were analysed using the Kjeldahl method according to the AOAC [24] procedure. Crude protein $(\mathrm{CP})$ was calculated as $\mathrm{N} \times 6.25$. The ether extracts (EE) content was determined by using Ankom $^{\mathrm{XT15}}$ analyser [25]. The analyses of neutral detergent fibre (NDF) and acid detergent fibre (ADF) contents of the leaves were based on the method of Van Soest et al. [26] using an Ankom fibre analyser. Condensed tannin (CT) contents of the leaves were determined according to Makkar et al. [27].

\subsection{In vitro gas (Hohenheim) production technique}

Three infertile Holstein cows with ruminal cannulas (average live weight $650 \mathrm{~kg}$ ) were used in the in vitro gas production technique. Approximately $200 \mathrm{mg}$ dry weight of samples were weighed in triplicate into $100 \mathrm{ml}$ calibrated glass syringes (Model Fortuna from Germany) following the procedures of Menke and Steingass [28]. The syringes were pre-warmed at $399^{\circ} \mathrm{C}$ before the injection of $30 \mathrm{ml}$ rumen fluid $(10 \mathrm{ml})$ buffer mixture $(20 \mathrm{ml})$ (1:2) into each syringe and incubated in a water bath at $39 \stackrel{\circ}{\circ}$. Gas volumes were recorded at $0,3,6,9,12,24,48,72$ and 96 hours of incubations. Five replications of each leaf were used for the in vitro study. Rumen fluid was obtained from the fistulated Holstein cows fed twice daily (08.3016.30) with a diet containing forage (corn silage, $60 \%$ ) and concentrates (40\%). The data were fitted to the model of Ørskov and McDonald [29] by NEWAY computer package programme.

$$
\mathrm{y}=\mathrm{a}+\mathrm{b}\left(1-\mathrm{exp}^{-\mathrm{ct}}\right)
$$

Where; a: the gas production from the immediately soluble fraction $(\mathrm{ml})$, b: the gas production from the insoluble fraction $(\mathrm{ml}), \mathrm{a}+\mathrm{b}$ : potential gas production (ml), c: the gas production rate constant for the insoluble fraction $(\mathrm{ml} / \mathrm{h})$, t: incubation time $(\mathrm{h})$, y: gas produced at a time " $t$ ".

Organic matter digestibility (OMD), metabolizable energy $(\mathrm{ME})$ and net energy lactation $\left(\mathrm{NE}_{\mathrm{L}}\right)$ contents of the leaves were estimated according to the equations given at below used for forages.

OMD, $\%=14.88+0.8893 \mathrm{GP}+0.448 \mathrm{CP}+0.651$ ash [30]

$\mathrm{ME}, \mathrm{MJ} / \mathrm{kg} \mathrm{DM}=2.20+0.136 \mathrm{GP}+0.057 \mathrm{CP}+0.002859 \mathrm{EE}^{2}[30]$

$\mathrm{NE}_{\mathrm{L}}, \mathrm{MJ} / \mathrm{kg} \mathrm{DM}=0.101 \mathrm{GP}+0.051 \mathrm{CP}+0.11 \mathrm{EE}[28]$

Where; GP: $24 \mathrm{~h}$ net gas production (ml/200mg DM), CP: Crude protein (\%), EE: Ether extract (\%)

\subsection{Determining relative feed values of samples}

The relative feed value (RFV) of leaves was calculated as follows [31];

DMI $=$ Dry matter intake $($ Live Weight $=$ LW \% $)=120 /($ NDF \% $)$

DMD $=$ Dry matter digestibility $(\%)=88.9-(0.779$ x ADF \% $)$ 
$\mathrm{RFV}=$ Relative feed value $=(\mathrm{DMD} \times \mathrm{DMI}) / 1.29$

\subsection{Statistical analysis}

Completely Randomized Design was used to compare chemical composition, gas production, and gas production kinetics of SOL, ML and OL using General Linear Model of SPSS (SPSS version 10.0) package programmes. Significance between individual means was identified using the Duncan's multiple comparison test. To observe the relations among traits Canonical correlation analysis was performed but the results among variable sets were found statistically insignificant $(\mathrm{P}>0.05)$. In this situation, Pearson correlation coefficients were calculated to show relations among traits.

\section{Results}

Nutrient contents of the tree leaves are given in Table 1. The findings of this study indicated that the ML had the highest CP, EE and NDF and had the lowest DM content $(\mathrm{P}<0.01)$. SOL had the highest DM and had the lowest NDF contents $(\mathrm{P}<0.01)$. OL had the highest ADF and had the lowest $\mathrm{CP}$ contents $(\mathrm{P}<0.01)$. In terms of $\mathrm{CP}$ contents, all the leaves in the study showed values $(6.85-13.68 \%$ $\mathrm{DM})$ which were higher than the straws with low quality roughage sources. In the study, it was determined that the CT contents of the leaves were generally low (between 0.46-1.06\% DM). The lowest CT content was found in OL where the highest CT content was observed in ML. There was no significant difference in CT between ML and SOL $(P>0.05)$.

Relative feed values and forage qualities of the tree leaves are given in Table 2. This indicates that all the leaves were significantly different from each other $(\mathrm{P}$ $<0.01)$ and they were placed into a low quality roughage class. However, the highest DMD, DMI and RFV values were found to be SOL while the lowest values were ML $(\mathrm{P}<0.05)$

In vitro gas production of the leaves were given in Table 3 and Figure 1. There was no difference in terms of in vitro gas production between the leaves at the beginning of incubation (3 hours incubation) ( $\mathrm{P}>0.05)$. However, the highest IVGP values for 6,9 , and 12 hours incubation were SOL where the highest IVGP values for $24,48,72$ and 96 hours incubation were observed in ML $(\mathrm{P}<0.01)$. Olive leaves were determined to have lower IVGP values than the other leaves for 24, 48, 72 and 96 hours incubation (P $<0.01$ ).

In vitro gas production kinetics, estimated energy values (ME and $\mathrm{NE}_{\mathrm{L}}$ ) and organic matter digestibility of the tree leaves are given in Table 4. In terms of $a+b$ value, OMD, ME and NEL in the study, the highest values were determined in ML followed by SOL. The lowest values for

Table 1. Chemical compositions and condensed tannin contents of the leaves (as DM\%)

\begin{tabular}{llllllll}
\hline & DM & CP & EE & Ash & NDF & ADF & CT \\
\hline Leaves & $\%$ & DM $\%$ & & & & & \\
\hline SOL & $43.37 \mathrm{a}$ & $8.00 \mathrm{~b}$ & $1.80 \mathrm{~b}$ & $19.65 \mathrm{a}$ & $27.84 \mathrm{c}$ & $26.14 \mathrm{~b}$ & $0.92 \mathrm{a}$ \\
ML & $31.17 \mathrm{c}$ & $13.68 \mathrm{a}$ & $5.18 \mathrm{a}$ & $19.61 \mathrm{a}$ & $47.81 \mathrm{a}$ & $25.90 \mathrm{~b}$ & $1.06 \mathrm{a}$ \\
OL & $42.80 \mathrm{~b}$ & $6.85 \mathrm{c}$ & $2.43 \mathrm{~b}$ & $5.86 \mathrm{~b}$ & $39.93 \mathrm{~b}$ & $30.32 \mathrm{a}$ & $0.46 \mathrm{~b}$ \\
SEM & 0.00 & 0.11 & 0.41 & 0.16 & 0.99 & 0.42 & 0.10 \\
Significant & 0.533 & 0.00 & 0.00 & 0.00 & 0.00 & 0.00 & 0.01 \\
\hline
\end{tabular}

a,b,c..: Means with different supercripts in the same column are significantly different. DM: Dry matter, CP: Crude protein, EE: Ether extracts, NDF: Neutral detergent fibre, ADF: Acid detergent fibre, CT: condensed tannin, SEM: Standard error of means

Table 2. Relative feed values and forage qualities of the leaves

\begin{tabular}{lllll}
\hline Leaves & DMD, \% & DMI, \% BW & RFV & RFV Quality \\
\hline SOL & $41.95 \mathrm{a}$ & $1.87 \mathrm{a}$ & $60.80 \mathrm{a}$ & 5 \\
ML & $24.14 \mathrm{c}$ & $0.79 \mathrm{c}$ & $14.71 \mathrm{c}$ & 5 \\
OL & $33.71 \mathrm{~b}$ & $1.29 \mathrm{~b}$ & $33.62 \mathrm{~b}$ & 5 \\
SEM & 0.86 & 0.02 & 1.07 & \\
Significant & $<0.000$ & $<0.000$ & $<0.000$ & \\
\hline
\end{tabular}

a,b,c..: Means with different supercripts in the same column are significantly different. SEM: Standard error of means, According to the Quality Grading Standard assigned by The Hay Marketing Task Force of the American Forage and Grassland Council, the RFV were assessed as roughages based on prime $>151,1$ (premium) 151-125, 2 (good). 124-103. 3 (fair). 102-87, 4 (poor). 86-75, 5(reject). $<75$. 


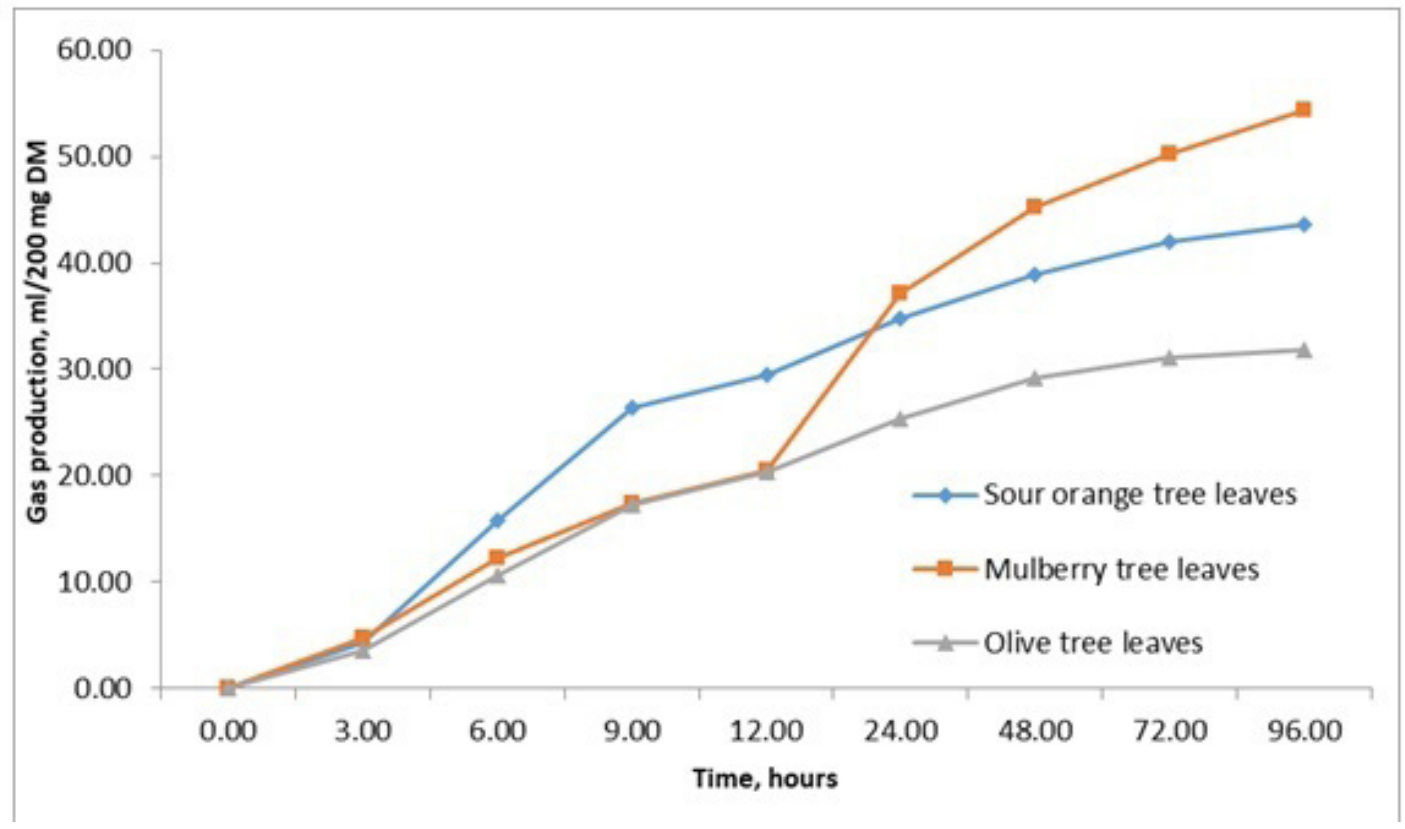

Figure 1. In vitro gas productions of the tree leaves

Table 3. In vitro gas production of the leaves ( $\mathrm{ml} / 200 \mathrm{mg} \mathrm{DM})$

\begin{tabular}{|c|c|c|c|c|c|c|c|c|}
\hline \multirow[b]{2}{*}{ Leaves } & \multicolumn{8}{|c|}{ Incubation times, hour } \\
\hline & 3 & 6 & 9 & 12 & 24 & 48 & 72 & 96 \\
\hline SOL & 4.38 & $15.78 \mathrm{a}$ & $26.33 a$ & $29.51 a$ & $34.82 b$ & $38.87 b$ & $42.06 b$ & $43.64 b$ \\
\hline ML & 4.82 & $12.33 b$ & $17.40 \mathrm{~b}$ & $20.58 b$ & $37.18 a$ & $45.20 \mathrm{a}$ & $50.24 a$ & $54.29 a$ \\
\hline $\mathrm{OL}$ & 3.64 & $10.58 \mathrm{c}$ & $17.34 b$ & $20.43 b$ & $25.37 c$ & $29.25 c$ & $31.07 c$ & $31.80 c$ \\
\hline SEM & 0.35 & 0.38 & 0.32 & 0.29 & 0.46 & 0.42 & 0.59 & 0.55 \\
\hline Significant & 0.14 & 0.00 & 0.00 & 0.00 & 0.00 & 0.00 & 0.00 & 0.00 \\
\hline
\end{tabular}

$\mathrm{a}, \mathrm{b}, \mathrm{c}$ Column means with common superscript do not differ, $\mathrm{P}<0.05$. SEM: Standard error of means

Table 4. in vitro gas production kinetics and $\mathrm{pH}$ values after 96. $\mathrm{h}$ incubation of the tree leaves

\begin{tabular}{lllllll}
\hline Leaves & $\mathrm{pH}^{*}$ & $\mathrm{a}+\mathrm{b}$ & $\mathrm{c}$ & OMD & ME & NEL \\
\hline SOL & $6.84 \mathrm{a}$ & $40.82 \mathrm{~b}$ & $0.13 \mathrm{a}$ & $50.73 \mathrm{~b}$ & $7.40 \mathrm{~b}$ & $4.12 \mathrm{~b}$ \\
ML & $6.69 \mathrm{c}$ & $53.13 \mathrm{a}$ & $0.05 \mathrm{c}$ & $55.38 \mathrm{a}$ & $8.11 \mathrm{a}$ & $5.02 \mathrm{a}$ \\
OL & $6.75 \mathrm{~b}$ & $30.53 \mathrm{c}$ & $0.10 \mathrm{~b}$ & $40.91 \mathrm{c}$ & $6.06 \mathrm{c}$ & $3.18 \mathrm{c}$ \\
SEM & 0.006 & 0.486 & 0.002 & 0.410 & 0.063 & 0.047 \\
Significant & 0.00 & 0.00 & 0.00 & 0.00 & 0.00 & 0.00 \\
\hline
\end{tabular}

a, b, c Column means with common superscript do not differ, a+b: potential gas production (ml), c: the gas production rate constant for the insoluble fraction (ml/h), OMD: organic matter digestibility (\%), ME: metabolisable energy (MJ/kg DM), NEL: net energy lactation (MJ/kg $\mathrm{DM}), \mathrm{P}<0.05 .{ }^{*}$ : $\mathrm{pH}$ values after $96 . \mathrm{h}$ incubation

these parameters were observed in OL $(\mathrm{P}<0.01)$. In this study, the highest gas production rate was observed in SOL, but OL and ML were following $(\mathrm{P}<0.01)$. In the study, the $\mathrm{pH}$ values after 96 hours of incubation indicated whether the buffer solution was sufficient or not for normal rumen conditions. According to this, the highest $\mathrm{pH}$ value was observed in SOL (6.84), where OL and ML were succeeding; 6.75 and 6.69 respectively. Therefore, it can be said that the buffer solution was not completely consumed until the end of the incubation period by microorganisms and the amount of buffer did not affect the results of this study.

Pearson correlation coefficients were calculated to show relations among traits, the largest positive correlation was observed between crude protein and EE. The largest negative correlation was observed between NDF and DMI, 
RFV (Table 5). The largest relations with gas production with nutrient contents were found between $6 \mathrm{~h}$ and $12 \mathrm{~h}$ (Table 6). When the Pearson correlation coefficients were examined, it is clear that observations on consecutive time points were highly related (Table 7 ). The highest positive correlation was observed between crude protein and $\mathrm{pH}$.
The highest negative correlation was observed between dry matter and $\mathrm{pH}$ (Table 8). The highest correlated traits with ME among b, ab and OMD (Table 9). For the traits given in Table 10 was highly correlated gas production after $24 \mathrm{~h}$ incubation times than before $24 \mathrm{~h}$ incubation times (Table 10).

Table 5. Pearson correlation coefficients with NDF, ADF, EE, CT, DMD, DMI and RFV.

\begin{tabular}{|c|c|c|c|c|c|c|c|c|c|}
\hline & NDF & ADF & $\mathrm{EE}$ & Ash & $\mathrm{CP}$ & CT & DMD & DMI & RFV \\
\hline DM & $-0,812$ & 0,485 & $-0,922$ & $-0,461$ & $-0,979$ & $-0,565$ & 0,893 & 0,862 & 0,831 \\
\hline NDF & & 0,094 & 0,861 & $-0,117$ & 0,685 & 0,081 & $-0,976$ & $-0,991$ & $-0,991$ \\
\hline$A D F$ & & & $-0,302$ & $-0,954$ & $-0,641$ & $-0,820$ & 0,040 & $-0,006$ & $-0,075$ \\
\hline $\mathrm{EE}$ & & & & 0,321 & 0,888 & 0,422 & $-0,906$ & $-0,870$ & $-0,846$ \\
\hline Ash & & & & & 0,628 & 0,837 & $-0,043$ & 0,047 & 0,104 \\
\hline $\mathrm{CP}$ & & & & & & 0,673 & $-0,790$ & $-0,745$ & $-0,703$ \\
\hline CT & & & & & & & $-0,224$ & $-0,146$ & $-0,100$ \\
\hline DMD & & & & & & & & 0,986 & 0,985 \\
\hline DMI & & & & & & & & & 0,996 \\
\hline
\end{tabular}

DM: Dry matter, CP: Crude protein, EE: Ether extracts, NDF: Neutral detergent fibre, ADF: Acid detergent fibre, CT: condensed tannin, DMD: Dry matter digestibility, DMI: Dry matter intake, RFV: Relative feed value

Table 6. Pearson correlation coefficients of NDF, ADF, EE, CT, DMD, DMI and RFV with in vitro incubation times.

\begin{tabular}{lllllllll}
\hline & $\mathbf{3}$ & $\mathbf{6}$ & $\mathbf{9}$ & $\mathbf{1 2}$ & $\mathbf{2 4}$ & $\mathbf{4 8}$ & $\mathbf{7 2}$ & $\mathbf{9 6}$ \\
\hline DM & $-0,132$ & $-0,928$ & $-0,994$ & $-0,995$ & $-0,364$ & $-0,159$ & $-0,125$ & $-0,070$ \\
NDF & 0,490 & 0,901 & 0,785 & 0,794 & 0,808 & 0,679 & 0,657 & 0,613 \\
ADF & 0,518 & $-0,247$ & $-0,524$ & $-0,512$ & 0,570 & 0,730 & 0,760 & 0,785 \\
EE & 0,197 & 0,860 & 0,906 & 0,909 & 0,441 & 0,274 & 0,246 & 0,191 \\
Ash & $-0,548$ & 0,174 & 0,490 & 0,484 & $-0,649$ & $-0,797$ & $-0,814$ & $-0,847$ \\
CP & 0,004 & 0,853 & 0,980 & 0,979 & 0,172 & $-0,041$ & $-0,074$ & $-0,130$ \\
CT & $-0,256$ & 0,377 & 0,577 & 0,561 & $-0,436$ & $-0,576$ & $-0,616$ & $-0,637$ \\
DMD & $-0,409$ & $-0,928$ & $-0,865$ & $-0,874$ & $-0,702$ & $-0,550$ & $-0,528$ & $-0,477$ \\
DMI & $-0,462$ & $-0,941$ & $-0,839$ & $-0,846$ & $-0,778$ & $-0,631$ & $-0,605$ & $-0,560$ \\
RFV & $-0,489$ & $-0,918$ & $-0,802$ & $-0,810$ & $-0,806$ & $-0,671$ & $-0,648$ & $-0,604$
\end{tabular}

DM: Dry matter, CP: Crude protein, EE: Ether extracts, NDF: Neutral detergent fibre, ADF: Acid detergent fibre, CT: condensed tannin, DMD: Dry matter digestibility, DMI: Dry matter intake, RFV: Relative feed value

Table 7. Pearson correlation coefficients with in vitro incubation times.

\begin{tabular}{llllllll}
\hline Incubations & $\mathbf{6}$ & $\mathbf{9}$ & $\mathbf{1 2}$ & $\mathbf{2 4}$ & $\mathbf{4 8}$ & $\mathbf{7 2}$ & $\mathbf{9 6}$ \\
\hline 3 & 0,451 & 0,141 & 0,130 & 0,663 & 0,664 & 0,665 & 0,662 \\
6 & & 0,932 & 0,929 & 0,609 & 0,426 & 0,391 & 0,346 \\
9 & & 0,999 & 0,340 & 0,129 & 0,095 & 0,040 \\
12 & & & 0,348 & 0,137 & 0,105 & 0,048 \\
24 & & & & 0,975 & 0,966 & 0,952 \\
48 & & & & & 0,998 & 0,996 \\
72 & & & & & & & \\
\hline
\end{tabular}


Table 8. Pearson correlation coefficients of DM, NDF, ADF, EE, ash, CP CT, DMD, DMI and RFV with pH, b, $c$ and a+b values, OMD, ME and NE

\begin{tabular}{llllllll}
\hline & $\mathbf{p H}$ & $\mathbf{b}$ & $\mathbf{c}$ & $\mathbf{a + b}$ & $\mathbf{O M D}$ & $\mathbf{M E}$ & $\mathbf{N E}_{\mathbf{L}}$ \\
\hline DM & $-0,902$ & $-0,445$ & $-0,737$ & 0,010 & $-0,241$ & $-0,212$ & $-0,053$ \\
NDF & 0,505 & 0,855 & 0,216 & 0,551 & 0,733 & 0,713 & 0,597 \\
ADF & $-0,770$ & 0,506 & $-0,923$ & 0,830 & 0,670 & 0,687 & 0,786 \\
EE & 0,771 & 0,520 & 0,575 & 0,120 & 0,336 & 0,309 & 0,166 \\
Ash & 0,784 & $-0,579$ & 0,932 & $-0,887$ & $-0,744$ & $-0,762$ & $-0,856$ \\
CP & 0,960 & 0,258 & 0,853 & $-0,208$ & 0,044 & 0,015 & $-0,147$ \\
CT & 0,768 & $-0,369$ & 0,884 & $-0,684$ & $-0,526$ & $-0,548$ & $-0,649$ \\
DMD & $-0,637$ & $-0,763$ & $-0,369$ & $-0,409$ & $-0,613$ & $-0,589$ & $-0,458$ \\
DMI & $-0,570$ & $-0,829$ & $-0,295$ & $-0,493$ & $-0,694$ & $-0,672$ & $-0,546$ \\
RFV & $-0,524$ & $-0,854$ & $-0,240$ & $-0,540$ & $-0,729$ & $-0,708$ & $-0,588$
\end{tabular}

DM: Dry matter, CP: Crude protein, EE: Ether extracts, NDF: Neutral detergent fibre, ADF: Acid detergent fibre, CT: condensed tannin, DMD: Dry matter digestibility, DMI: Dry matter intake, RFV: Relative feed value, $\mathrm{pH}$ : after for 96 hour incubation, b: potential gas production, c: gas production rate, OMD: organic matter digestibility, ME: Metabolisable energy, NEL: net energy lactation

Table 9. Pearson correlation coefficients of $\mathrm{pH}, \mathrm{b}, \mathrm{c}, \mathrm{a}+\mathrm{b}, \mathrm{OMD}, \mathrm{ME}$ with $\mathrm{b}, \mathrm{c}$ and $\mathrm{a}+\mathrm{b}$ values, OMD, ME and $\mathrm{NE}_{\mathrm{L}}$

\begin{tabular}{|c|c|c|c|c|c|c|}
\hline Parameters & b & c & $a+b$ & OMD & ME & $\mathbf{N}_{\mathrm{EL}}$ \\
\hline $\mathrm{pH}$ & 0,043 & 0,938 & $-0,419$ & $-0,181$ & $-0,209$ & $-0,362$ \\
\hline b & & $-0,273$ & 0,887 & 0,973 & 0,966 & 0,914 \\
\hline c & & & $-0,682$ & $-0,474$ & $-0,499$ & $-0,631$ \\
\hline$a+b$ & & & & 0,967 & 0,973 & 0,997 \\
\hline OMD & & & & & 1,000 & 0,982 \\
\hline$M E$ & & & & & & 0,987 \\
\hline
\end{tabular}

$\overline{\mathrm{pH}}$ : after for 96 hour incubation, b: potential gas production, c: gas production rate, $\mathrm{a}+\mathrm{b}$ : total gas production, OMD: organic matter digestibility, ME: Metabolisable energy, NEL: net energy lactation

Table 10. Pearson correlation coefficients of in vitro incubation times with $\mathrm{pH}, \mathrm{b}, \mathrm{c}$ and $\mathrm{a}+\mathrm{b}$ values, $\mathrm{OMD}, \mathrm{ME}$ and $\mathrm{NE}_{\mathrm{L}}$

\begin{tabular}{lllllllll}
\hline Incubations & $\mathbf{p H}$ & $\mathbf{b}$ & $\mathbf{c}$ & $\mathbf{a + b}$ & $\mathbf{O M D}$ & $\mathbf{M E}$ & $\mathbf{N E}_{\mathbf{L}}$ \\
\hline 3 & $-0,233$ & 0,598 & $-0,341$ & 0,661 & 0,680 & 0,680 & 0,676 \\
6 & 0,700 & 0,656 & 0,502 & 0,272 & 0,505 & 0,481 & 0,338 \\
9 & 0,905 & 0,415 & 0,754 & $-0,040$ & 0,214 & 0,186 & 0,025 \\
12 & 0,908 & 0,425 & 0,748 & $-0,032$ & 0,222 & 0,194 & 0,033 \\
24 & $-0,052$ & 0,993 & $-0,355$ & 0,924 & 0,991 & 0,987 & 0,948 \\
48 & $-0,260$ & 0,953 & $-0,548$ & 0,985 & 0,995 & 0,997 & 0,993 \\
72 & $-0,291$ & 0,941 & $-0,578$ & 0,990 & 0,991 & 0,994 & 0,995 \\
96 & $-0,345$ & 0,922 & $-0,621$ & 0,997 & 0,984 & 0,988 & 0,999 \\
\hline
\end{tabular}

pH: after for 96 hour incubation, b: potential gas production, c: gas production rate, a+b: total gas production, OMD: organic matter digestibility, ME: Metabolisable energy, NEL: net energy lactation 


\section{Discussion}

In this study, it was determined that the crude protein contents of olive leaves were lower than those (7.0-12.9\% DM) reported by Martin-Garcia et al. [13] and Shakeri et al. [32] . The NDF, ADF and ash contents of the olive leaves were found to be similar to those reported in the literature (34.9-41.5\% DM), (24.5-34.2\% DM) and (5.40$6.93 \%$ DM) respectively [16, 32-35]. It has been reported in the literature that the amount of CT in olive leaves varies between $0.58-1.11 \%$ DM $[16,35-37]$, the CT value determined in the study was $0.46 \%$, which was lower than those reported in the previous studies. It has reported that the observed differences were due to the origin of the olive leaves, the leaf-branch ratio, storage and climate conditions, the level of the soil or oil contaminations and the drying process applied [38]. Martin-Garcia and Molina-Alcaide [35] reported that the application of different drying processes was an important effect on the CT content of olive leaves, where the highest CT content was determined in the fresh - form of the leaves (1.0\% DM) and the lowest CT content was found to be those dried in the oven at $60^{\circ} \mathrm{C}(0.62 \% \mathrm{DM})$.

Karabulut et al. [21] determined that CP (12.9\%), NDF (29.5\%), ADF (25.3\%), ash (10.4\%) and CT (0.59\%) contented in Citrus aurantium leaves. The CP content $(8.0 \%)$ determined in this study was lower; the CT content (0.92\%) was higher, and the NDF (27.84\%) and ADF $(26.14 \%)$ were similar to result reported by Karabulut et al. [21]. Yao et al. [39] reported that the nutrient contents of the ML harvested in the spring DM (23.6-24.4\%), CP (20.8-21.6\% DM) and NDF (37.5-39.5\% DM) have changed when compared to those harvested in the autumn (29.630.45\% DM, 19.6- 21.9\% DM, 38.9-43.4\% DM respectively); the CP content has decreased as harvesting is delayed while NDF content increased. It was thought that the variations observed were due to the difference in varieties, characteristics of the soil grown, time of harvesting, fertilization, drying process, leaf-branch ratio, species, climate etc. [38, 40, 41].

Karabulut et al. [21] reported the total gas production for SOL as $76.9 \mathrm{ml} / 200 \mathrm{mg} \mathrm{DM}$ and the gas production rate "c" as $6.7 \mathrm{ml} /$ hour. These values were determined as 40.82 $\mathrm{ml} / 200 \mathrm{mg} \mathrm{DM}$ and $0.13 \mathrm{ml} /$ hour in the present study, respectively, and were lower than those reported in the literature.

Karabulut et al. [21] reported the OMD and ME contents of SOL as $73.3 \%$ and $10.9 \mathrm{MJ} / \mathrm{kg}$ DM respectively. The OMD $(50.73 \%)$ and $\mathrm{ME}(7.40 \mathrm{MJ} / \mathrm{kg} \mathrm{DM})$ values determined in this study were lower than those reported in the previous studies. The main reason for this is that the 24 hour gas production in the equations used for the calculation was low.

Mulberry tree leaves have high DM and OM digestibility (82-89\% DM), high CP (14.0-18.6\% DM), low NDF (24.627.6\% DM) and low ADF (20.8-25.1\% DM) contents with high ash (13.3-14.3\% DM) content [42, 43]. Guven [41] reported that chemical contents (DM: 25.97-42.20\%; CP: 11.7523.72\%; ash: 15.40-22.36\%; CT: 0.47-0.76\%) can be affected by different species of ML. In this study, the CP, NDF, ADF and ash contents were determined as 13.68, 47.81, 25.90 and $19.61 \% \mathrm{DM}$, respectively, and the variations observed were related to the factors such as variety, soil structure, harvest time, season etc. [38, 41]. However, it is thought that ML to be forage feed source that can be used to feed ruminants. It is clear that low CT content will not affect the consumption of animals in the negative direction. It is also known that young ML has higher rumen degradability [42] and it should be taken into consideration that the feeding value of young leaves is higher.

Karabulut et al. [21] reported that there is a negative relationship between 24 hour gas production with $\mathrm{CP}$, NDF and ADF contents of leaves. However, the findings obtained in this study were different from this report. Having high CP and NDF content, ML has the highest 24 hour gas production value. Yao et al. [39] report that in vitro gas production of ML showed higher values when harvested in spring (43.9-52.7 ml) than those harvested in autumn (36.7-38.0 ml). When harvested in autumn, it was determined the $\mathrm{c}$ value as $6.16-7.01 \mathrm{ml} /$ hour, 24 hour gas production 30.8-31.3 ml/200mg DM and OMD values as 58.4-60.1\%; but, when harvested in the spring, they were determined as 7.26-9.5 ml/hour, 39.6-47.6 ml/200mg DM and $65.9-71.9 \%$, respectively. It can be seen, that the harvesting season has also a significant effect on the in vitro gas production and gas production parameters. In this study, the c value obtained from ML was lower than those in the literature, but the values of $a+b$ and 24 hour gas production were found to be similar to leaves harvested in the spring. The OMD value determined in the study was also close to that of autumn harvested leaves in the literature reports. It is thought that the differences seen were due to variation in nutrient content (higher amount of ash, lower CP content) [40].

Shakeri et al. [32] reported the in vitro gas production of olive leaves as $245-247 \mathrm{ml} / \mathrm{g}$ DM (49-49.4 ml/200 mg DM). These values were considerably higher than the total gas production $(\mathrm{a}+\mathrm{b}=30.53 \mathrm{ml} / 200 \mathrm{mg} \mathrm{DM})$ and gas production obtained after 96 hours incubation $(31.80 \mathrm{ml}$ / 200mg DM). However, Shakeri et al. [32] reported that the use of OL reduced total gas and methane production in ruminants. This suggests that the use of olive leaves 
in certain ratio in the ruminant feeding will provide significant environmental benefits and that the energy of the feeds will be better utilized.

In this study, all leaves were found to be significantly different in relative feed values $(\mathrm{P}<0.01)$, and they fall into a low quality roughage feed class. It was found that the RFV values of citrus leaves were similar to the RFV values of wheat and soybean straws reported by Mohamoud Abdi and Kilic [44] and Kilic and Gulecyuz [45], while the RFV values of other leaves were lower than these straws. According to the wheat and soybean straws, ruminants will have less voluntary feed intake of the ML with the lowest DMI value and the SOL will be consumed more.

The findings of each leaf in this study supported the fact that the anti-nutritive factors like tannins may also contribute to a reduction of in vitro gas production. Kamalak et al. [7] reported that in tree leaves a condensed tannins can be found in the bound and soluble form. Karabulut et al. [21] reported a negative correlation between CT with 24 hour gas production and OMD and ME. According to that, it was expected that ML with the highest CT content will have the lowest in vitro gas production. As shown in Figure 1, the IVGP value determined in the ML, which has the highest CT content in leaves up to 24 hours, was lower than the IVGP values determined in the SOL; the higher values for OL were thought to be related to the CT release in the rumen environment. The low IVGP value of ML up to 24 hour incubation can be due to the high release of ML contained CT into the rumen during first 24 hours. The reason for this, is that the amount of CT remaining in the ML structure will decrease after 24 hours of incubation and the amount of CT released into the rumen will be low, resulting in an increase of IVGP value.

It was suggested that CT contents of $5-10 \%$ may result disgust of feeds, reduces forage consumption and live weight gain, decreases digestibility and absorption, reduce performance and lead toxicity related effects [46]. Since the CT contents of leaves used in this study were between $0.46-1.06 \%$, it is believed that this will not have an adverse effect on the feed consumption. As a result, it was concluded that the sour orange, the mulberry and the olive tree leaves used in the study can be utilized as alternative roughage source for ruminants if it is used within certain limits in the feeding (adding 5-10\% into the ration) after being dried in a condition that the loss of leaves is reduced. Thus, this would have economic benefits and advantages for the closure of the forage feed gaps.

It has reported that ammonia and urea treatment have positive effects on improving the nutritive value of olive leaves [47, 48]. When the olive leaves (treated with ammonia) were compared with the alfalfa hay as roughage in lactating sheep, there was no difference among the groups in terms of milk yield, but the group fed with olive leaf was reported to contain more oleic acid and linoleic acid [49]. In terms of milk yield, milk fat and protein content, no adverse effect was observed in sheep and goats consumed olive leaves freely [50]. In addition, it seems that supplement of olive leaves has no negative effect on feed intake and utilization. In general, it is advisable to use ML and SOL in animal feeding after being processed like OL through above mentioned procedures.

\section{Conclusions}

It is concluded that there were significant differences among tree leaves in terms of chemical composition and potential gas production. Fermentation characteristics of $\mathrm{OL}$ in vitro were identified as having the potential to modulate rumen fermentation. It was also found that OL reduced in vitro gas production in comparing to ML and SOL. The leaves had beneficial effects on rumen fermentation. However, these results need to be confirmed further with in vivo studying, before these products can be advanced further in goats and sheep nutrition. CT contents should be taken into account and used in limited amounts in the ruminant rations.

\section{Conflict of interest: Authors state no conflict of interest}

\section{Abbreviation List}

$a+b$ : Potential gas production $(\mathrm{ml})$,

ADF: Acid detergent fibre

c: The gas production rate constant for the insoluble fraction $(\mathrm{ml} / \mathrm{h})$,

CF: Crude fibre

CP: Crude protein

CT: Condensed tannin

DM: Dry matter

EE: Ether extract

ME: Metabolisable energy (MJ/kg DM),

ML:Mulberry tree leaves

NDF: Neutral detergent fibre

$\mathrm{NE}_{\mathrm{L}}$ : Net energy lactation (MJ/kg DM), NFE: Nitrogen free extracts

OL: Olive tree leaves

OMD: Organic matter digestibility (\%),

SOL: Sour orange tree leaves. 


\section{References}

[1] Boga M. Chemical Composition and in vitro Gas Production Kinetics of Some Tree Leaves Obtained in The Mediterranean Region of Turkey. Anadolu J Agr Sci, 2014;29(2):143-146.

[2] Kilic U, Boga M, Guven I. Chemical composition and nutritive value of oak (Quercus robur) nut and leaves. J. Appl. Anim. Res., 2010;38:101-104.

[3] Kamalak A, Canbolat O, Atalay Al, Kaplan M. Determination of potential nutritive value of young, old and senescent leaves of Arbutus and rachne tree. J. Appl. Anim. Res., 2010;37:257-260.

[4] Ates S, Nefzaoui A, Keles G. The Role and Management of Pastures and Fodder Resources In Integrated CropLivestock Systems in West Asia-North Africa. VII. National Animal Nutrition Congress (International Participantion), 26-27 September 2013, p. 29-37 Ankara-Turkey.

[5] Atalay Al, Ozkan CO, Kaya E, Kurt O, Kamalak A. Effect of maturity on chemical composition and nutritive value of leaves of Arbutus andrachne shrub and rumen in vitro methane production. Livestock Research for Rural Development. 2017;29:138. http://www.lrrd.org/lrrd29/7/akam29138.html

[6] Papachristou TG, Papanastasis VP. Forage value of Mediterranean deciduous woody fodder species and its implication to management of silvo-pastoral systems for goats. Agroforestry systems, 1994;27:269-282.

[7] Kamalak A, Canbolat O, Gurbuz, Y, Ozay O, Ozkose E. Chemical composition and its relationship to in vitro gas production of several tannin containing trees and shrub leaves. Asian Austral. J. Anim. Sci. 2005;18:203-208.

[8] Leng RA. Tree Foliage In Ruminant Nutrition. FAO Animal Production and Health, 1997; Paper-139. FAO, United Nations, Rome.

[9] Rababah TM, Ereifej KI, Al-Mahasneh MA, Alhamad MN, Alrababah MA, Muhammad AH. The Physicochemical Composition of Acorns for Two Mediterranean Quercus Species. Jordan Journal of Agricultural Sciences, 2008;4(2):131-137.

[10] Provenza FD. Postingestive feedback as an elementary determinant of food selection and intake in ruminants. Journal of Range Management, 1995;48:2-17.

[11] Kilic U, Mohamoud Abdi A. Determination of in vitro true digestibilities and relative feed values of wine industry grape residues as alternative feed source. Kafkas Univ Vet Fak Derg., 2016;22(6):895-901.

[12] Delgado-Pertinez M, Chesson A, Provan GJ, Garrido A, Gomez-Cabrera A. Effect of different drying systems for the conservation of olive leaves on their nutritive value for ruminants. Ann. Zootech. 1998;47:141-150.

[13] Martin-Garcia Al, Yanez-Ruiz DR, Moumen A, Molina-Alcaide E. Effect of polyethylene glycol, urea and sunflower meal on olive (Olea europaea var. europaea) leaf fermentation in continuous fermentors. Small Rumin. Res. 2006;61:53-61.

[14] Amici A, Verna M, Martillotti F. Olive byproducts in animal feeding: Improvement and utilization. Options Mediterraneennes- Serie Seminaires, 1991;16:149-152.

[15] Khorchani T, Hammadi M, Hammami H, Ben-Rouina B. Use of olive by- products in the nutrition of lambs in Southern Tunisia. In: Lindberg JE, Gonda HL, Ledin I. (eds). Recent. Adv. Small Rumin. Nutr. Zaragoza: CIHEAM-IAMZ, 1997;99-102.
[16] Martin-Garcia Al, Moumen A, Yanez-Ruiz DR, Molina-Alcaide E. Chemical composition and nutrients availability for goats and sheep of two stage olive cake and olive leaves. Anim. Feed Sci. Technol. 2003;107:61-74.

[17] FAO. Animal Feed Resources Information System from the original book named Tropical Feeds by Bo Göhl - database by Speedy A and Waltham N. 8th Edition. FAO, 1998 Rome. http:// www.fao.org/WAICENT/FAOINFO/AGRICULT/AGA/AGAP/FRG/ TFEED8/index.htm

[18] Roothaert RL. Feed intake and selection of tree fodder by dairy heifers. Anim. Feed Sci. Technol., 1999;79(1-2):1-13.

[19] Kirbaslar G, Kirbaslar I. Composition of Turkish Bitter Orange and Lemon Leaf Oils. Journal of Essential Oil Research. 2004;16(2):105-108.

[20] Babazadeh Darjazi B. Comparison of leaf components of sweet orange and sour orange (Citrus sp.). Int J Adv Biol Biom Res. 2013;1(12):1558-1568.

[21] Karabulut A, Canbolat O, Ozkan CO, Kamalak A. Determination of nutritive value of citrus tree leaves for sheep using in vitro gas production technique. Asian-Aust. J. Anim. Sci., 2007;20(4):529-535.

[22] Temel S, Tan M. Fodder values of shrub species in maquis in different altitudes and slope aspects. The J. Anim. Plant Sci., 2011;21:508-512.

[23] Sagocak AT. Determination of potential nutritive value of leaves Arbutus adrachne. Kahramanmaras Sutcu Imam UniversityTurkey. (MSc Thesis). pp. 1-63. 2011.

[24] AOAC. Officinal Methods of Analysis. 16th Edition, AOAC International, Gaithersburg, MD. 1998.

[25] AOCS. Official procedure, approved procedure Am 5-04, Rapid determination of oil/fat utilizing high temperature solvent extraction. J Am Oil Chem Soc. 2005; Urbana, IL.

[26] Van Soest PV, Robertson JB, Lewis BA. Methods for dietary fiber, neutral detergent fiber, and nonstarch polysaccharides in relation to animal nutrition. J. Dairy Sci., 1991; 74(10):3583-3597.

[27] Makkar HPS, Blummel M, Becker K. Formation of complexes between polyvinyl pyrrolidones or polyethylene glycols and their implication in gas production and true digestibility in vitro techniques. British Journal of Nutrition, 1995;73,897-913.

[28] Menke KH, Steingass H. Estimation of the Energetic Feed Value Obtained from Chemical Analysis and in vitro Gas Production Using Rumen Fluid. Anim. Res. Devel, 1998;28:7-55.

[29] Ørskov ER, McDonald I. The estimation of protein degradability in the rumen from incubation measurements weighted according to rate of passage. J Agr Sci., 1979;92:499-503.

[30] Menke KH, Raab L, Salewski A, Steingass H, Fritz D, Schneider W. The estimation of the digestibility and metabolizable energy content of ruminant feeding stuffs from the gas production when they are incubated with rumen liquor in vitro. J. Agric. Sci. Camb. 1979;93:217-222.

[31] Rohweder DA, Barnes RE, Jorgensen N. Proposed hay grading standards based on laboratory analysis for evaluating quality. J. Anim. Sci. 1978;47:747-759.

[32] Shakeri P, Durmic Z, Vadhanabhuti J, Vercoe PE. Products derived from olive leaves and fruits can alter in vitro ruminal fermentation and methane production. J. Sci. Food Agric., 2017;97:1367-1372.

[33] Molina-Alcaide E, Yanez-Ruiz D, Moumen A, Martin-Garcia I. Chemical composition and nitrogen availability for goats 
and sheep of some olive by-products. Small Rumin. Res. 2003,49:329-336.

[34] Molina-Alcaide E, Yanez-Ruiz DR. Potential use of olive by-products in ruminant feeding: A review. Anim. Feed Sci. Technol. 2008;147:247-264.

[35] Martin-Garcia Al, Molina Alcaide E. Effect of different drying procedures on the nutritive value of olive (Olea europaea var. europaea) leaves for ruminants. Anim. Feed Sci. Technol. 2008;142:317-329.

[36] Molina-Alcaide E, Yanez-Ruiz DR, Moumen A, Martin-Garcia Al. Ruminal degradability and in vitro intestinal digestibility of sunflower meal and in vitro digestibility of olive by-products supplemented with urea or sunflower meal comparison between goats and sheep. Anim. Feed Sci. Technol. 2003,110:3-15.

[37] Yanez-Ruiz DR., Martin-Garcia Al, Moumen A, Molina-Alcaide E. Ruminal fermentation and degradation patterns, protozoa population and urinary purine derivatives excretion in goats and wethers fed diets based on olive leaves. J. Anim. Sci. 2004;82:3006-3014.

[38] Keser O, Bilal T. The Use of Olive-by products in Animal Nutrition. Animal Production, 2010;51(1):64-72.

[39] Yao J, Yan B, Wang XQ, Liu XJ. Nutritional evaluation of mulberry leaves as feeds for ruminants. Livestock Research for Rural Development, 2000;12:2. http://www.cipav.org.co/lrrd/ Irrd12/2/yao122.htm

[40] Kilic U. Nutritive values of whole-crop wheat hay and silage and effect of microbial inoculants on in vitro gas production. J. Appl. Anim. Res., 2010;37:67-71.

[41] Guven I. Effect of species on nutritive value of mulberry leaves. Kafkas Univ Vet Fak Derg, 2012;18(5):865-869.

[42] Shayo CM. Uses, yield and nutritive value of mulberry (Morus alba) trees for ruminants in the semi-arid areas of central Tanzania. Tropical Grasslands, 1997; 31: 599-604.
[43] Omar SS, Shayo CM, Uden P. Voluntary intake and digestibility of mulberry (Morus alba) diets by goats. In: The potential of mulberry (Morus alba) as fodder tree for goats in semi-arid Tanzania. Swedish University of Agricultural Sciences. (MSc. Thesis). 1988.

[44] Mohamoud Abdi A, Kilic U. Effect of Lignin Peroxidase Enzyme on Feed Values Of Different Straws. KSU J Agric Nat. 2018;21(3) Doi: 10.18016/ksudobil.346585.

[45] Kilic U, Gulecyuz E. Effects of Some Additives on In Vitro True Digestibility of Wheat and Soybean Straw Pellets. Open Life Sci., 2017; 12:206-213.

[46] Kamalak A. Feed Additives and Some Chemical Treatment to Decrease the Negative Effect of Condensed Tannin. KSU Journal of Natural Sciences. 2007; 10(2):144-150.

[47] Singh K, Rai SN, Singh GP, Gupta BN. Solid state fermentation of urea-ammonia treated wheat straw and rice straw with Comprinus fimetarius. Indian J. Microbiol. 1998;29:371-376.

[48] Fayed AM, El Ashry MA, Hend AA. Effect of feeding olive tree pruning by-products on sheep performance in Sinai. World J. Agric. Sci. 2009;5(4):436-445.

[49] Fegeros K, Zervas G, Apsokardos F, Vastardis J, Apostolaki E. Nutritive evaluation of ammonia treated olive tree leaves for lactating sheep. Small Rumin. Res. 1995;17:9-15.

[50] Tsiplakou E, Zervas G. The effect of dietary inclusion of olive tree leaves and grape marc on the content of conjugated linoleic acid and vaccenic acid in the milk of dairy sheep and goats. J. Dairy Res. 2008;75:270-278. 